\title{
GENETIC POLYMORPHISM OF STREPTOCOCCUS MUTANS IN BRAZILIAN FAMILY MEMBERS
}

\section{Denise Madalena Palomari Spolidorio ${ }^{1 *}$; José Francisco Höfling²; Antônio Carlos Pizzolitto ${ }^{3}$ Edvaldo Antonio Rosa²; Thaís de Cássia Negrini ${ }^{1}$; Luís Carlos Spolidorio ${ }^{1}$}

\begin{abstract}
${ }^{1}$ Departamento de Fisiologia e Patologia, Faculdade de Odontologia de Araraquara, Universidade Estadual Paulista Júlio de Mesquita Filho, Araraquara, SP, Brasil. ²Departamento de Biologia e Patologia Buco-Dental, Faculdade de Odontologia de Piracicaba, Universidade Estadual de Campinas, Piracicaba, SP, Brasil. ${ }^{3}$ Departamento de Análises Clínicas, Faculdade de Ciências Farmcêuticas de Araraquara, Universidade Estadual Júlio de Mesquita Filho, Araraquara, SP, Brasil.
\end{abstract}

Submitted: December 08, 2002; Returned to Authors: July 10, 2003; Approved: August 28, 2003

\begin{abstract}
The aim of this study was to determine whether random amplified polymorphic DNA (AP-PCR) analysis is able to differentiate genetically different clones of mutans streptococci, in 22 Brazilian family members. Stimulated saliva samples were collected from fathers, mothers and infants. For 5-18 months babies with erupting primary dentition, plaque samples were collected using sterile tooth pick tips. From these samples, mutans streptococci were isolated on $\mathrm{SB}_{-20}$ agar plates. After growth, representative colonies were identified by biochemical methods on the basis of carbohydrate fermentation. Streptococcus mutans isolates were obtained from all family members and AP-PCR typed separately with a random primer (OPA-13). Bacterial cell lysates were used as template in PCR reactions and the amplified DNA fragments obtained were compared by agarose gel electrophoresis. Results demonstrated that the father shared the baby's genotype in three families and the mother shared the baby's genotype in 12 families seven babies harbored Streptococcus mutans strains similar to those of their siblings. The technique was able to demonstrate the genetic Streptococcus mutans in Brazilian family members.
\end{abstract}

Key words: Streptococcus mutans; AP-PCR; genetic polymorphism.

\section{INTRODUCTION}

Mutans streptococci, particulary Streptococcus mutans, are the main bacterial species that initiate human dental caries $(24,32)$. The fact that animal dental caries is an infectious and transmissible disease was first demonstrated by Keyes (17). These organisms can not be detected in the oral cavity at birth and normal predentate infants do not harbor Streptococcus mutans until some time after teeth emerge (11). Several studies suggest that children become infected as a result of maternal transfer. Other possible transmission routes, such as extrafamilial acquisition of mutans streptococci in children, intrafamilial transmission between mother, father and child, and transmission between spouses, have been reported $(3,4,7,8,9$,
18,22,27,28). Studies on the transmission and acquisition of mutans streptococci have been performed on families living in westernized countries, and this information is still limited with regard to other countries.

Mutans streptococci have been classified into seven different species: S. criceti, S. ratti, S. mutans, S. sobrinus, $S$. macacae, $S$. downei $(25,34)$ and $S$. orisratti sp. nov. (35). The identification of these species is initially based on the recognition of morphological differences in colonies appearence on selective mitis-salivarius agar plates (15). Species are identified by biochemical, physiological and serological tests $(2,6,8,14,16)$. Over the last two decades several molecular typing methods have become available, some of which have been applied to oral streptococci, such as bacteriocin typing $(12,26)$, plasmid

*Corresponding author. Mailing address: Departamento de Fisiologia e Patologia, Faculdade de Odontologia, Universidade Estadual de Paulista Júlio de Mesquita Filho. Rua Humaitá, 1680, Centro. 14801-903, Araraquara, SP, Brasil. Tel.: (+5516) 201-6480. Fax: (+5516) 201-6488. E-mail: dmps@foar.unesp.br 
profile (8), or fingerprinting techniques $(9,10,20,21,23,29,30,33,35)$ have also been used. Of these, a PCR-based DNA fingerprinting procedure, called arbitrarily PCR (AP-PCR) analysis, has particularly been used for strain identification and typing of oral streptococci.

The aim of this study was to determine whether random amplified polymorphic DNA (AP-PCR) analysis is able to identify intra-familial mutans streptococci, working with 22 Brazilian families.

\section{MATERIALS AND METHODS}

\section{Bacterial isolates}

A total of 410 mutans streptococci isolates, isolated from saliva or plaque samples of members from 22 families comprising father, mother, infant (first born child) and 5-18 month-old-baby, were selected for the present study.

\section{Saliva and plaque dental collection}

A piece of paraffin gum-base, of approximately $1.5 \mathrm{~g}$, was supplied to the mother, father and child of each family. Each individual chewed the gum-base for about 30 seconds. Approximately $2.0 \mathrm{~mL}$ of stimulated saliva were collected in sterile glass tubes. Plaque samples were collected from the teeth of each baby using the tips of sterile wooden toothpicks. The tip with plaque sample was placed in $2.0 \mathrm{~mL}$ of $0.05 \mathrm{M}$ sterile phosphate buffer ( $\mathrm{pH}$ 7.3).

Each flask containing the saliva and plaque samples was vortexed for 1 minute to obtain an uniform suspension. Samples were diluted in a decimal series $\left(10^{-1}\right.$ to $\left.10^{-4}\right)$ in $0.05 \mathrm{M}$ phosphate buffer, $\mathrm{pH}$ 7.3. Aliquots of $25 \mu \mathrm{L}$ of each dilution were inoculated in Bacitracin Sucrose Agar - SB-20 ${ }^{12}$ (Difco). The plates were incubated for $48 \mathrm{~h}$ in candle jars at $37^{\circ} \mathrm{C}$. Four colonies representing the morphological types of mutans streptococci from each subject were then isolated and identity confirmed by their fermentation pattern (31). After identification, S. mutans cultures were maintained at $4^{\circ} \mathrm{C}$ for up to 2 weeks on BHI medium. For long-term storage, cultures were kept at $-20^{\circ} \mathrm{C}$ in $10 \%$ glycerol BHI broth (Difco).

\section{Chromosomal DNA isolation and purification}

DNA was extracted according to Bert et al. (5) with some modifications. Strains were grown overnight at $37^{\circ} \mathrm{C}$ in $20 \mathrm{~mL}$ BHI (Difco). The cells were washed twice in TE buffer $(50 \mathrm{mM}$ Tris, $1 \mathrm{mM}$ EDTA, $\mathrm{pH}$ 8), centrifuged and resuspended in a buffer containing $10 \mathrm{mM}$ Tris-HCl, $50 \mathrm{mM}$ EDTA and 25\% sucrose. DNA was released from bacterial cells by incubation with $10 \mathrm{mg} / \mathrm{mL}$ lysozyme (Pharmacia Biotech, Sweden) and $100 \mu \mathrm{g} / \mathrm{mL}$ RNAase (Pharmacia Biotech, Sweden) for $30 \mathrm{~min}$ at $60^{\circ} \mathrm{C}$, followed by incubation with $10 \mathrm{mg} / \mathrm{mL}$ proteinase $\mathrm{K}$ (Amersham Life Science, UK) and 10\% sarkosyl (Pharmacia Biotech, Sweden) for $2 \mathrm{~h}$ at $37^{\circ} \mathrm{C}$ and then for $30 \mathrm{~min}$ at $68^{\circ} \mathrm{C}$.
The pellets were treated several times with phenol: chloroform: isoamylalcohol (25:24:1) and finally DNA was precipitated with cold ethanol. DNA was dried, suspended in TE buffer and stored at $-20^{\circ} \mathrm{C}$.

\section{AP-PCR typing}

The OPA-13 primer was obtained from Operon Techonologies. The base sequence of the primer was (5'-3') CAGCACCCAC.

A $25 \mu \mathrm{L}$ reaction mixture containing $10 \mathrm{mM}$ Tris- $\mathrm{HCl}, \mathrm{pH} 8$, $4 \mathrm{mM} \mathrm{MgCl}_{2}, 0.4 \mathrm{mM}$ of dNTP mix (Pharmacia Biotech, Sweden), $0.4 \mu \mathrm{M}$ primer, $50 \mathrm{ng}$ DNA, and $2.5 \mathrm{U}$ Taq polymerase (Gibco BRL, USA) was amplified for streptococci mutans using APPCR. The reaction mixture was thermocycled (Perkin-Elmer Cetus thermocycler, USA) employing an initial denaturation at $94^{\circ} \mathrm{C}$ for $5 \mathrm{~min}$ followed by 45 cycles of $94^{\circ} \mathrm{C}$ for $30 \mathrm{~s}$, annealing at $36^{\circ} \mathrm{C}$ for $30 \mathrm{~s}$ and extension at $72^{\circ} \mathrm{C}$ for $1 \mathrm{~min}$, with a single final extension at $72^{\circ} \mathrm{C}$ for $3 \mathrm{~min}$. Amplification products were analyzed electrophoretically on $1.4 \%$ agarose gel, detected with ethidium bromide (Pharmacia Biotech, Sweden) and photographed with DC 40 camera digital imaging systems for electrophoresis gel documentation and analysis (Kodak Digital Science ${ }^{\mathrm{TM}}$, USA) under UV-light. Data were analyzed by Kodak 1D Image Analysis Software. The degree of similarity among strains was calculated using the simple matching coefficient. A data matrix, scoring each amplicon as 1 (present) or 0 (absent), was then compiled. Dendrograms were constructed from the results obtained with the single primer.

Information generated as binary data were processed using the NTSYS-pc system version 1.70 (Applied Biostatistcs, 1992), in which the qualitative program and the similarity Simple Matching Coefficient were used to compare the samples.

\section{RESULTS}

Pure isolates from 22 mothers, 22 fathers, 22 infants and 22 babies were analyzed.

From a total of 410 isolates selected from SB-20 plates, 374 $(91.2 \%)$ were identified as S. mutans. One same primer and strain produced reproducible DNA banding profiles of the amplification products. Amplification of DNA from the Streptococcus mutans strains with the OPA-13 primer resulted in 6-9 fragments (amplicons), ranging from 0.5 to $2.0 \mathrm{~kb}$ in size. Figure 1 shows an example of the DNA-fingerprint patterns of S. mutans strains obtained with OPA-13 primer. Other families results are not shown. In general, strains with similar or identical DNA fingerprints were easily recognized visually (Fig. 1 and 2). The AP-PCR fingerprints showed only a limited subset of amplicons. Several bands were species-specific, whereas others were found in only one or few strains, indicating polymorphism in the specie. Fig. 3 and 4 show the dendrogram obtained with AP-PCR of strains obtained from members of two families. 


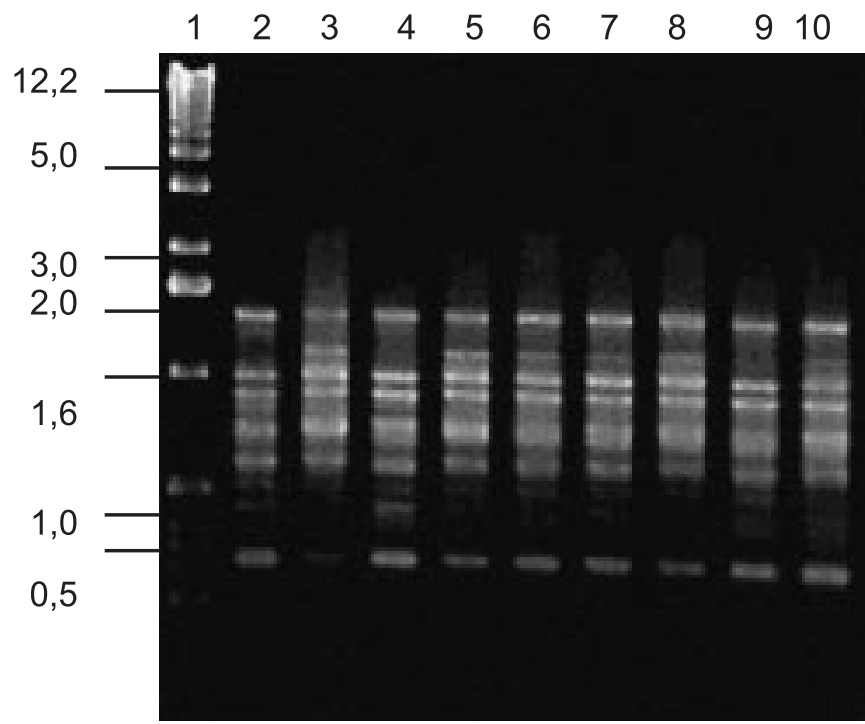

Figure 1. DNA-fingerprints of Streptococcus mutans strains from different families. 1: Mol. Wt markers (1 Kb ladder).; 2: strain S. mutans; 3 and 7: Father (F); 4 and 8: Mother (M); 5 and 9: son 1 (S1); 6 and 10: son 2 (S2) baby.

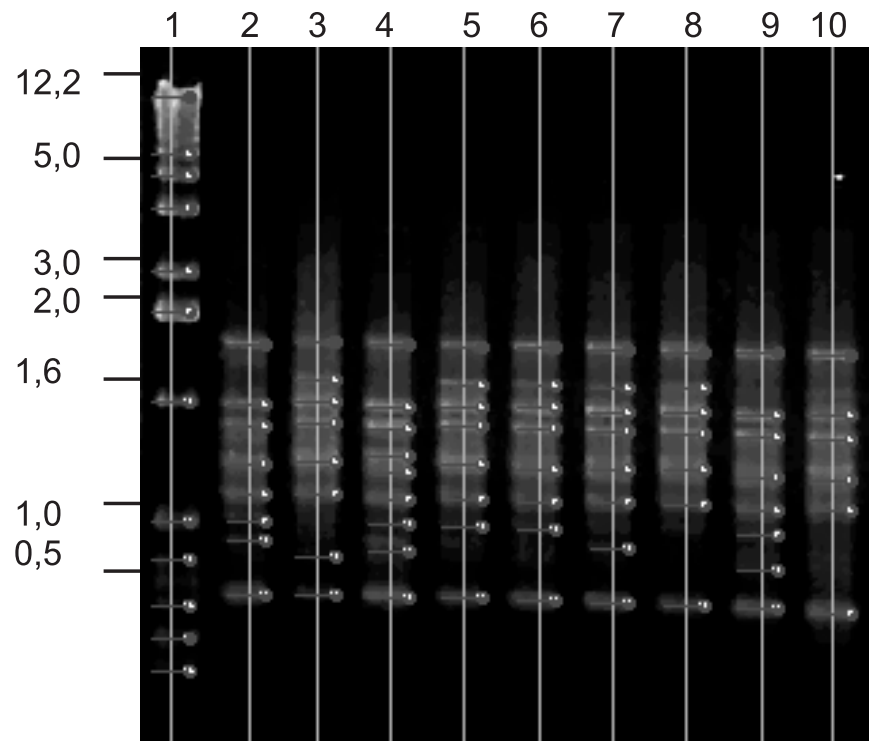

Figure 2. Diagram of DNA-fingerprints of Streptococcus mutans strains from different families. 1: Mol. Wt markers (1 Kb ladder); 2: strain S. mutans; 3 and 7: Father (F); 4 and 8: Mother (M); 5 and 9: son 1 (S1); 6 and 10: son 2 (S2) baby.

Among 22 families analyzed, three fathers harboured similar strains of $S$. mutans to their infants. Twelve babies harbored similar $S$. mutans strains to their mothers and seven babies harbored $S$. mutans strains similar to those of their siblings

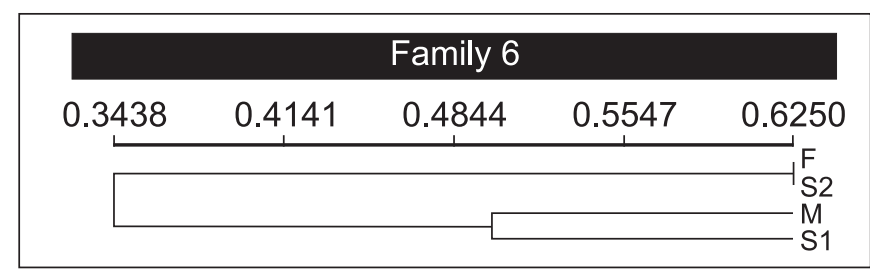

Figure 3. Dendrogram of similarity of Streptococcus mutans from Family 06 (F6). Father (F); Mother (M); son 1(S1); son 2 (S2) baby.

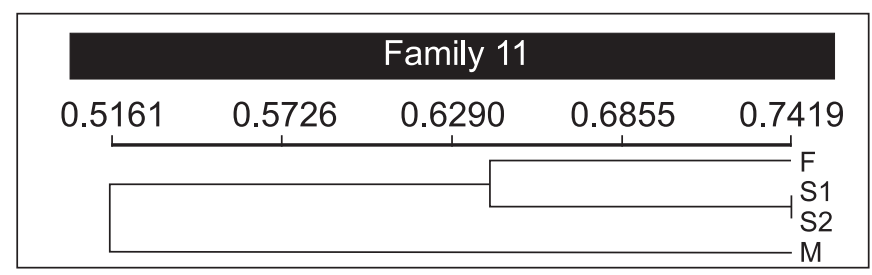

Figure 4. Dendrogram of similarity of Streptococcus mutans from Family 11 (F11). Father (F); Mother (M); son 1(S1); son 2 (S2) baby.

\section{DISCUSSION}

Several extraction methods for isolation of DNA of Streptococcus have been described $(1,5,30)$. The technique proposed by Saarela et al. (30) and used in this study presented advantages due to a larger number of amplicons.

The results obtained in this investigation using the OPA-13 primer (5) are expressed in Fig. 1 and 2. The AP-PCR technique has been used for inter- and intra-species discrimination among isolated microorganisms. In theory, random primers generate an amplification pattern which is consistent for groups of related species. It is commonly accepted that any polymorphism observed between related species or individuals is consed by modifications in base pairing by mutations, deletions or insertion of genetic elements.

The random primer utilized in the AP-PCR technique, OPA13, was able to efficiently generate sufficiently discernable electrophoretic patterns, as reported by Saarela et al. (30) and Li and Caulfield (23).

Results indicate that members of the same family harbor genetically different clones. A greater similarity (54.5\%) occurred between children and the mother, followed respectively between siblings (31.8\%) and between children and the father (13.7\%). Our results support the view that the intra-familial distribution of this cariogenic organism appears to vary from family to family.

Although research demonstrates that the main infection source for children is the mother, other sources of transmission should be considered. Our data are in agreement with those 
obtained by Redmo Emanuelsson and Wang (27), who found identical genotypes in fathers and in their first born children in Chinese families. Conversely, our results contrast with those of other authors $(7,18,19)$, who detected that more than $50 \%$ of the strains were shared by mothers and babies.

Berkowitz and Jones (3) and Davey and Rogers (12) also observed the intrafamilial transmission of Streptococcus since strains isolated from infants were similar to those of the parents or siblings. This fact is confirmed by the results expressed in Fig. 1 and 3 (other results not shown).

Epidemic studies have tried to elucidate the chain of transmission of the Streptococcus mutans group. Rogers (28) verified that in $88 \%$ of studied families, two or more members (one of which was a parent) shared common S. mutans strains. This, by itself, is not necessarily indicative of intra-familial transmission of the microorganism, but in several occasions, the child was infected with a type common to the family. Thus, in the familial intimacy, other persons, besides the parents, siblings or other relatives, may participate in the transmission of cariogenic microorganisms to children in their first month of life (13).

In the great majority of cases, AP-PCR is a highly efficient method for polymorphism detection of genetic variability, as confirmed by our results and those of Kulkarni et al. (21), who also demonstrated that the DNA fingerprinting method has a greater sensitivity and reproducibility when compared to other methods described in the literature. Kulkarni et al. (21) showed evidence of the intrafamilial transmission of Streptococcus mutans, in addition to transmission between couples, demonstrating the efficiency of this technique.

The data obtained in our research demonstrated that the use of molecular biology techniques, particularly AP-PCR, not only allows the detection of degrees of polymorphism among Streptococcus mutans isolates, but also facilitates the establishment of the level of intra-familial similarity between isolated strains, providing a deeper knowledge of these relationships.

The establishment of standardized methodologies of genetic typing for this group of microorganisms and, in the future, for other microorganisms of the oral cavity will be of fundamental importance for epidemiological studies in populations. The results obtained open possibilities for other new studies to investigate different populations and to improve the understanding of the mechanisms of intrafamilial transmission of microorganisms.

\section{ACKNOWLEDGMENTS}

This investigation was supported by FAPESP, Proc 97/073301. We thank Dr. Antonio Bento Alves de Moraes, responsible for the Baby's Clinic of Piracicaba Dental School - UNICAMP, Brazil.

\section{RESUMO}

\section{Polimorfismo genético de Streptococcus mutans em membros de famílias brasileiras}

O objetivo deste estudo foi determinar, através da técnica de reação em cadeia da polimerase com primers arbitrários (APPCR) a capacidade de diferenciar clones geneticamente distintos de Streptococcus mutans e estabelecer o grau de similaridade intrafamilial para os isolados. Para o presente estudo, foram selecionadas 22 famílias brasileiras. Amostras de saliva foram coletadas de todos os membros das famílias. Das crianças com idade entre 5-18 meses obteve-se amostras de placa dental. Após o isolamento das colônias com características morfológicas, realizou-se a identificação bioquímica com base na fermentação de carboidratos. O polimorfismo genético de Streptococcus mutans foi pesquisado através da técnica de AP-PCR utilizando-se o primer OPA-13. Os fragmentos de DNA obtidos foram amplificados e comparados através de eletroforese em gel de agarose. Dentre as espécies identificadas nas 22 famílias analisadas, o pai apresentou cepas com similaridade genética aos dos bebês em três das famílias analisadas; em 12 famílias a mãe apresentou cepas com similaridade com as cepas de Streptococcus mutans do bebê e 7 bebês apresentaram cepas de $S$. mutans com similaridade genética das cepas do irmão mais velho. A técnica de AP-PCR foi eficaz em demonstrar a heterogeneidade genética de Streptococcus mutans entre os membros das famílias brasileiras analisadas.

Palavras-chave: Streptococcus mutans; AP-PCR; polimorfismo genético.

\section{REFERENCES}

1. Alaluusua, S.; Mättö, J.; Grönroos, L.; et al. Oral colonization by more than one clonal type of mutans Streptococcus in children with nursing-bottle dental caries. Arch. Oral Biol., 41:167-173, 1996.

2. Beighton, D.; Russel, R.R.B.; Whiley, R.A. A sample biochemical scheme for the differentiation of $S$. mutans and S. sobrinus. Caries Res., 25:174-178, 1991.

3. Berkowitz, R.J.; Jones, P. Mouth-to-mouth transmission of the bacterium S. mutans between mother and child. Arch. Oral Biol., 30:377- 379, 1985.

4. Berkowitz, R.J.; Jordan, H.V. Similarity of bacteriocins of S. mutans from mother and infant. Arch. Oral Biol., 20:725-730, 1975.

5. Bert, F.; Picard, B.; Branger, C.; et al. Analysis of genetic relationships among strains of groups A, C and $\mathrm{G}$ streptococci by random amplified polymorphic DNA analysis. J. Med. Microbiol., 45:278-284, 1996.

6. Bratthall, D. Demonstration of five serological groups of streptococcal strain resembling S. mutans. Odontol. Rev., 21:143-52, 1970.

7. Caufield, P.W.; Cutter, G.R.; Dasanayake, A.P. Initial acquisition of mutans streptococci by infants: evidence for a discrete window of infectivity. J. Dent. Res., 72(1):37-45, 1993.

8. Caufield, P.W.; Ratanapridakul, K.; Allen, D.N.; et al. Plasmidcontaining strains of Streptococcus mutans cluster within family and racial cohorts: implications for natural transmission. Infect. Immun., 56:3216-3220, 1988. 
9. Caufield, P.W.; Walker, T.M. Genetic diversity within Streptococcus mutans evident from chromosomal DNA restriction fragment polymorphisms. J. Clin. Microbiol., 27:274-278, 1989.

10. Colby, S.M.; Harrington, D.J.; Russel, R.R. Identification and genetic characterisation of melibiose-negative isolates of $S$. mutans. Caries Res., 29:407-412, 1995.

11. Dasanayake, A.P.; Caufiled, P.W.; Cutter, G.R.; et al. Transmission of mutans streptococci to infants following short term application of na iodine-NaF solution to mothers' dentition. Community Dent. Oral Epidemiol., 21:136-142, 1993.

12. Davey, A.L.; Rogers, A.H. Multiple types of the bacterium Streptococcus mutans in the human mouth and their intra-family transmission. Arch. Oral Biol., 29:453-460, 1984.

13. Emilson, C.G.; Thorgelius, I. Prevalence of mutans streptococci and lactobacilli in elderly Swedish individuals. Scand. J. Dent. Res., 96:1421, 1988.

14. Facklam, R.R. Physiological differentiation of viridans streptococci J. Clin. Microbiol., 5:184-201, 1977.

15. Gold, O.G.; Jordan, H.V.; van Houte, J. A selective medium for Streptococcus mutans. Archs. Oral Biol., 18:1357-1364, 1973.

16. Hardie, J.M.; Bowden, G.H. Physiological classification of oral viridans streptococci. J. Dent. Res., 55:A166-176, 1976.

17. Keyes, P.H. The infectious and transmissible nature of experimental dental caries. Findings and implications. Arch. Oral Biol., 1:304320,1960

18. Köhler, B.; Bratthall, D. Intrafamilial levels of $S$. mutans and some aspects of the bacterial transmission. Scand. J. Dent. Res., 86:3542, 1978.

19. Köhler, B.; Bratthall, D.; Krasse, B. Preventive measures in mothers influence the establishment of the bacterium S. mutans in their infants. Arch. Oral Biol., 28:225- 231, 1983.

20. Kozai, K.; Wang, D.S.; Sandham, H.I.; et al. Changes in strains of mutans streptococci induced by treatment with chlorohexidine varnish. J. Dent. Res., 70:1252-1257, 1991.

21. Kulkarni, G.V.; Chan, K.H.; Sandham, H.J. An investigation into the use of restriction endonuclease analysis for the study of transmission of mutans streptococci. J. Dent. Res., 68:1155-1161, 1989.
22. Li, Y.; Caufield, P.W. Initial acquisition of mutans streptococci in an infant population. J. Dent. Res., 72:402, 1993.

23. Li, Y.; Caufield, P.W. Arbitrarily primed polymerase chain reaction fingerprinting for the genotypic identification of mutans streptococci from humans. Oral Microbiol. Immunol., 13:17-22, 1998.

24. Loesche, W.J. Ecology of S. mutans in the human month and evidence for its role in caries initiation. In: Simposium on Current Topics in Dental Caries, Matsuto, Japan. Proceedings 1982, p.180-197.

25. Loesche, W.J. Role of Streptococcus mutans in human dental decay. Microbiol. Rev., 50:353-380, 1986.

26. Masuda, N.; Shimamoto, T.; Kitomura, K.; et al. Transmission of Streptococcus mutans in some selected families. Microbios, 44:223232, 1985.

27. Redmo Emanuelsson, I.; Wang, X. Demonstration of identical strains of mutans streptococci within Chinese families by genotyping. Eur J. Oral Sci., 106:788-794, 1998.

28. Rogers, A.H. The source of infection in the intrafamilial transfer of S. mutans. Caries Res., 15:26-31, 1981.

29. Saarela, M.; Alaluusua, S.; Takei, T.; et al. Genetic diversity within isolates of mutans streptococci recognized by a sRNA gene probe. $J$. Clin. Microbiol., 31:584-587, 1993.

30. Saarela, M.; Hannula, J.; Matto, J.; et al. Typing of mutans streptococci by arbitrarily polymerase chain reaction. Arch. Oral Biol., 41(8-9):821-826, 1996.

31. Shklair, I.L.; Keene, H.J. A biochemical scheme for the separation of the five varieties of S. mutans. Arch. Oral Biol., 19:1079-1081, 1974.

32. Shklair, I.L.; Keene, H.J. Distribution and frequency of S. mutans in caries active individuals. J. Dent. Res., 51(3):882, 1972.

33. Truong, T.L.; Menard, C.; Mouton, C.; et al. Identification of mutans and other oral streptococci by random amplified polymorphic DNA analysis. J. Med. Microbiol., 49(1):63-71, 2000.

34. Whiley, R.A.; Russel, R.R.B.; Hardie, J.M.; et al. Streptococcus downei $s p$. Nov. for strains previously described as $S$. mutans serotype h. Int. J. Syst. Bact., 38:2509, 1988.

35. Zhu, H.; Willcox, M.D.P.; Knox, K.W. A new species of oral Streptococcus isolated from Sprague-Dawley rats, Streptococcus orisratti sp. nov. Inter. J. Syst. Evolut. Microbiol., 50:55-61, 2000. 